\title{
POSSIBLE INTERACTION OF GENDER AND AGE ON HUMAN SWALLOWING BEHAVIOR
}

\author{
Roberto Oliveira DANTAS'1 ${ }^{1}$ Leda Maria Tavares ALVES², Carla Manfredi dos SANTOS² and \\ Rachel de Aguiar CASSIANI²
}

\begin{abstract}
Context - The swallowing behavior is affected by age and possibly by gender. However, the interaction of the effects of age and gender on swallowing is not completely known. Objective - To evaluate the possibility of interaction of gender and age on human swallowing behavior. Method - Swallowing was evaluated in 89 healthy subjects by the water swallowing test, 43 men and 46 women aged 20-40 years (younger, $\mathrm{n}=38$ ), 41-60 years (middle-aged, $\mathrm{n}=31$ ) and 61-80 years (older, $\mathrm{n}=20$ ). Each subject ingested in triplicate $50 \mathrm{~mL}$ of water while precisely timed and the number of swallows needed to ingest all the volume was counted. Results - The interval between swallows was shorter and the volume in each swallow was smaller in women compared to men. In older subjects the time to ingest the $50 \mathrm{~mL}$ of water was longer, the interval between swallows was longer, and swallowing flow and volume in each swallow were smaller than in younger and middle-aged subjects. The swallowing flow was lower in women compared to men in younger subjects. The volume of each swallow was smaller in women than in men in younger and middle-aged subjects. There was no difference in swallowing flow and volume between older men and older women. Conclusion - Age and gender influence swallowing behavior, with the effect of gender being more evident in younger subjects and the effect of age being more evident in men.
\end{abstract}

HEADINGS - Age effect. Gender identity. Deglutition.

\section{INTRODUCTION}

Swallowing is a complex function that is controlled by the central pattern-generating circuitry of the brain-stem and peripheral reflexes, and is influenced by peripheral sensitivity of the mouth, pharynx and esophageal body ${ }^{(19)}$, functions that could be affected by age and gender ${ }^{(1,16)}$.

There are results showing that age and gender influence swallowing, with women having a slower oropharyngeal transit ${ }^{(10)}$, lower oropharyngeal flow ${ }^{(2,15)}$, longer laryngeal closure during swallowing ${ }^{(18)}$ and a possibly longer cricopharyngeal opening duration ${ }^{(18)}$. The aging process causes a lower flow of the bolus through the mouth and pharynx ${ }^{(6,16)}$ and a longer cricopharyngeal opening duration $^{(18)}$. An influence of age and gender on esophageal motility was also observed ${ }^{(7,8,11,26,27,28)}$. However, there are insufficient data about the interaction of age and gender on swallowing.

The objective of this investigation was to evaluate the interaction of gender and of the aging process on the results of the clinical evaluation of swallowing. The hypothesis was that there is interaction of the influence of gender and the influence of aging on swallowing.

\section{METHODS}

We studied 89 healthy subjects ( 43 men and 46 women aged 20-80 years) without neurological diseases, with no previous surgery in the upper gastrointestinal tract, and with no esophageal or gastric symptoms in the last 5 years. The subjects were divided into three age groups: younger (20-40 years, mean: $29.8 \pm 4.9$ years, $n=38,15$ men), middle-aged (41-60 years, mean: $52.1 \pm 5.8$ years, $n=31,16$ men), and older (61-80 years, mean: $67.3 \pm 4.9$ years, $n=20,12$ men). The study was approved by the Human Research Committee of the University Hospital of Ribeirão Preto, SP, Brazil. Written informed consent was obtained from all participants.

Swallowing behavior was evaluated by the previously described water swallowing test ${ }^{(3,5,12,15,16)}$. All subjects were evaluated in the sitting position. They were asked to drink $50 \mathrm{~mL}$ of water at room temperature from a plastic cup "as quickly and as comfortably as possible" while being timed. The chronometer was started when the first drop of water touched the lips and was stopped when the larynx of the volunteers came to rest after the last swallow. The volunteers performed sequential swallows without any breaks during each measurement. The swallowing test was performed in triplicate, with an interval of at least 30 seconds between measurements. The four researches involved in the project had previous training in timing the swallows and counting the number of swallows, determined from the number of upper movements of the larynx. Each measurement was performed in the presence of at least two researchers who agreed when to start and to stop the measurement.

\footnotetext{
Department of Medicine of the Medical School of Ribeirão Preto, University of São Paulo, Ribeirão Preto, SP Brazil.

There is no conflict of interest for RO Dantas, LMT Alves, CM Santos and RA Cassiani.

Department of Medicine of the Medical School of Ribeirão Preto, University of São Paulo (USP): ${ }^{2}$ Postgraduate Course Medical School of Ribeirão Preto USP, Ribeirão Preto, SP, Brazil.

Correspondence: Prof. Roberto Oliveira Dantas - Departamento de Clínica Médica da Faculdade de Medicina de Ribeirão Preto - USP - 14049-900 - Ribeirão Preto, SP Brasil. E-mail: rodantas@fmrp.usp.br
} 
In addition to the time and number of swallows needed to ingest $50 \mathrm{~mL}$ of water we calculated: a) inter-swallow interval: the time to complete the task, in seconds, divided by the number of swallows during the task; b) swallowing flow: volume drunk $(50 \mathrm{~mL})$ divided by the time taken to swallow it, in seconds; c) swallowing volume capacity: volume drunk $(50 \mathrm{~mL})$ divided by the number of swallows.

The statistical analysis was performed at the Center of Quantitative Methods (CEMEQ) of the Medical School of Ribeirão Preto, using a linear multiple effect model and the PROC Mixed feature of the SAS software version $9^{(10)}$. The differences were considered significant when $P<0.05$ in a two-tailed statistical analysis. The results are reported as mean and standard deviation unless otherwise stated.

\section{RESULTS}

There was no difference between men and women in the time or number of swallows needed to drink the $50 \mathrm{~mL}$ of water. The interval between swallows and the volume of each swallow were smaller in women compared to men (Table 1). The swallowing flow was also smaller in women but the difference did not reach significance $(P=0.07)$.

TABLE 1 . Results of the swallowing drinking test in asymptomatic men $(\mathrm{n}=43)$ and asymptomatic women $(\mathrm{n}=46)$. Mean (SD)

\begin{tabular}{lccc}
\hline & Men & Women & $\boldsymbol{P}$ \\
\hline Time (s) & $5.4(2.2)$ & $5.4(2.1)$ & 0.34 \\
Number & $4.1(1.7)$ & $4.3(1.4)$ & 0.15 \\
Interval (s) & $1.5(0.7)$ & $1.3(0.3)$ & $<0.01$ \\
Flow $(\mathrm{mL} / \mathrm{s})$ & $11.8(5.3)$ & $10.9(4.1)$ & 0.07 \\
Volume $(\mathrm{mL})$ & $16.5(10.5)$ & $12.8(3.9)$ & $<0.01$ \\
\hline
\end{tabular}

The analysis of the aging effect showed that the time to drink the $50 \mathrm{~mL}$ of water and the interval between swallows were longer, and the swallowing flow and the volume in each swallow were lower in older subjects than in younger and middle-aged subjects (Table 2).

TABLE 2. Results of the swallowing drinking test in asymptomatic subjects aged 20-40 years (younger, $\mathrm{n}=38$ ), $41-60$ years (middle-aged, $\mathrm{n}=31$ ) and $61-80$ years (older, $\mathrm{n}=20$ ). Mean $(\mathrm{SD})$

\begin{tabular}{lccc}
\hline & Younger & Middle & Older \\
\hline Time (s) & $5.2(2.1)$ & $5.1(1.9)$ & $6.5(2.2)^{*}$ \\
Number & $4.4(2.0)$ & $3.9(1.2)$ & $4.6(1.4)$ \\
Interval (s) & $1.3(0.5)$ & $1.3(0.4)$ & $1.5(0.6) *$ \\
Flow $(\mathrm{mL} / \mathrm{s})$ & $11.7(5.0)$ & $11.6(4.3)$ & $9.0(3.1) *$ \\
Volume $(\mathrm{mL})$ & $15.0(9.5)$ & $15.3(7.9)$ & $12.9(4.2) *$ \\
\hline
\end{tabular}

$* P<0.05$ vs younger and middle

The swallowing flow was lower in younger women compared with younger men (Figure 1), without difference between men and women in middle-aged and older subjects. The flow was lower in older than in younger men (Table 3 ). The volume of each swallow was smaller in younger and middle-aged women compared with younger and middle-aged men (Figure 2). The volume in each swallow was smaller in older than in young men (Table 3 ). There was no difference in swallowing flow or volume capacity between men and women of the older group.

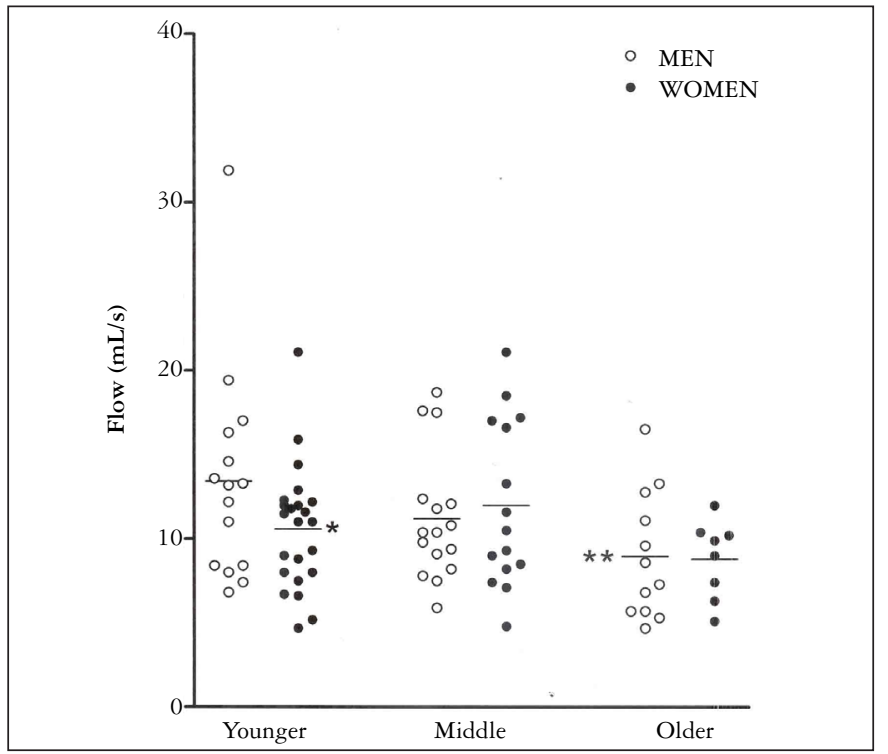

FIGURE 1. Swallowing flow of healthy subjects of the younger group, middle-aged group and older group. The horizontal bar represents the mean. $* P<0.05$ vs men $* * P<0.05$ vs younger men

TABLE 3. Swallowing flow and volume capacity in men and women of each age group. Mean (SD)

\begin{tabular}{lcccccc}
\hline & \multicolumn{3}{c}{ Flow $(\mathrm{mL} / \mathrm{s})$} & \multicolumn{3}{c}{ Volume $(\mathrm{mL})$} \\
\hline & Men & Women & $P$ & Men & Women & $\boldsymbol{P}$ \\
\hline Younger & $13.4(6.2)$ & $10.6(3.6)$ & 0.04 & $18.9(9.0)$ & $12.3(4.1)$ & 0.03 \\
Middle & $11.2(3.7)$ & $12.0(4.8)$ & $>0.05$ & $17.2(9.4)$ & $13.4(3.8)$ & 0.04 \\
Older & $8.9(3.6) *$ & $9.1(2.1)+$ & $>0.05$ & $13.4(4.8)^{*}$ & $12.1(2.9)+$ & $>0.05$ \\
\hline
\end{tabular}

$* P<0.05$ vs younger and middle

$+P<0.05$ vs middle

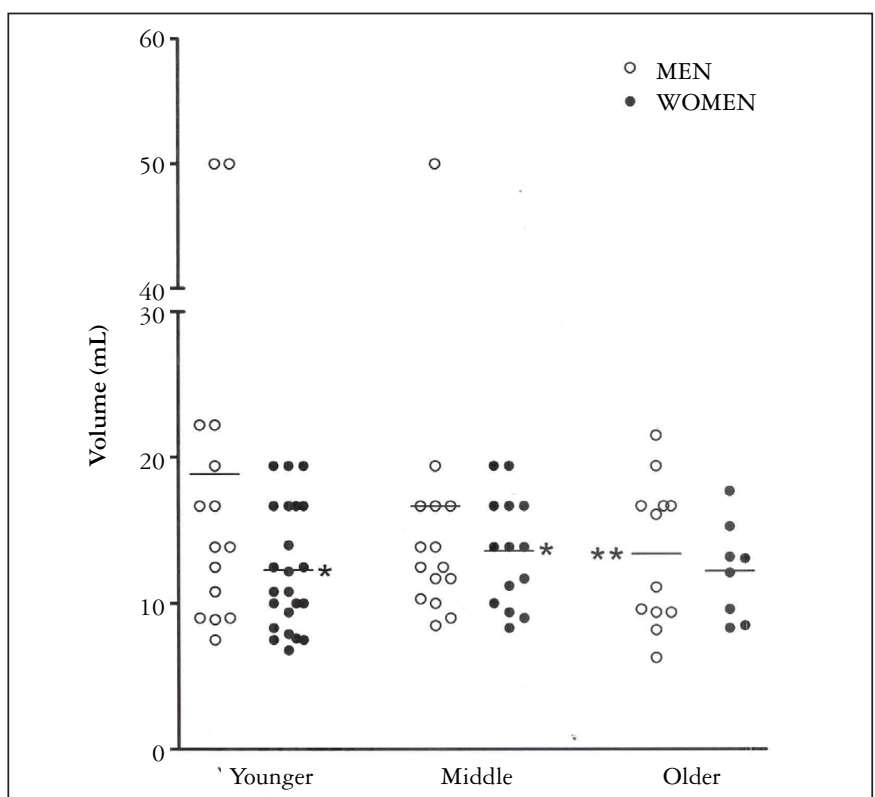

FIGURE 2. Swallowing volume capacity of healthy subjects of the younger group, middle-aged group and older group. The horizontal bar represents the mean. $* P<0.05$ vs men $* * P<0.05$ vs younger men 


\section{DISCUSSION}

This investigation demonstrated that gender and aging have influence on swallowing behavior.

Anatomical and functional differences between men and women have been described regarding the mouth, pharynx, upper esophageal sphincter (UES) and esophagus ${ }^{(2,7,14,16,22)}$. Compared to men, women have a longer oropharyngeal transit $^{(10)}$, longer UES opening duration ${ }^{(21,25)}$, shorter interswallow interval, lower swallowing flow, lower volume in each swallow ${ }^{(2,16)}$, a longer laryngeal closure during swallowing ${ }^{(18)}$, and an early laryngeal closure before the UES opening ${ }^{(18)}$.

Manometric examination revealed a longer duration of UES relaxation ${ }^{(27)}$, longer duration of oropharyngeal pressure $^{(24)}$, longer proximal ${ }^{(8)}$ and longer $\operatorname{distal}^{(7)}$ peristaltic esophageal contraction duration in women. Males are able to put inside their mouth a larger volume of water than females ${ }^{(20,22)}$, a fact that may explain the larger volume of water of each swallow observed in men compared to women.

An increase in the number of subjects with dysphagia is observed in the older population ${ }^{(1)}$, a problem that should be important in the near future, as the proportion of subjects older than 70 years is increasing in the population. Compared to younger subjects, older subjects have higher amplitude and longer duration of hypopharyngeal pressure ${ }^{(26)}$, lower UES resting pressure ${ }^{(26,27)}$, an increase in the amount of pharyngeal residues, prolonged oral transit, prolonged pharyngeal transit, prolonged pharyngeal clearance ${ }^{(6)}$, and a longer UES opening duration ${ }^{(18)}$.

The proximal esophageal contraction has a later response to swallowing and a shorter duration in older subjects than in younger subjects ${ }^{(11)}$. The duration of supraglottis closure and the maximal vertical excursion of the hyoid bone are increased in older subjects compared to younger ones ${ }^{(17)}$. In the distal esophageal body there was longer duration of contraction and an increase in the observation of simultaneous and failed contraction ${ }^{(1,13)}$.
In this investigation we evaluated the effect of age on men and women separately. The results showed that the difference in swallowing observed between men and women is seen in subjects younger than 40 years. The alteration of swallow behavior of old subjects is more intense in men than in women, and after 60 years of age the swallowing flow and the volume in each swallow are similar in men and women.

A previous publication reported that the swallowing flow and the swallowing volume capacity are greater in men than in women and that both swallowing flow and swallowing volume decrease with the aging process ${ }^{(16)}$. This previous investigation included older subjects than those studied here. From these results it is possible to say that gender and age influence swallowing behavior. However, gender differences in swallowing are not so impressive in older subjects as in younger subjects. The gender effect should be mainly due to anatomical and hormonal differences between genders, and the aging effect should be a consequence of neuronal degeneration during the aging process ${ }^{(1)}$.

The knowledge that age and gender have influence on swallowing has implications in the diagnosis and treatment of patients with swallowing disorders. Knowing that swallowing does not have the same behavior in older and younger subjects, and in males and females, we should take this difference into consideration when performing videofluoroscopy and fiberoptic nasoendoscopy evaluation of swallowing, and when applying swallowing therapies, dietary modification and drugs for patients with dysphagia.

The water swallowing test has been used in several investigations $\mathrm{s}^{(2,3,4,5,9,12,14,15,22,23)}$. It is easy to perform, although its needs some training, and is inexpensive and reproducible ${ }^{(3)}$. It can be used for comparison of swallowing behavior and to characterize difficulty in swallowing.

In conclusion, age and gender have influence on swallowing behavior, with the effect of gender being more significant in younger than in older subjects. Males have a higher swallowing flow and are able to ingesta greater volume in each swallow than females. The aging process causes a decrease in swallowing flow and in swallowing volume capacity.

Dantas RO, Alves LMT, Santos CM, Cassiani RA. Possível interação entre gênero e idade na deglutição. Arq Gastroenterol. 2011;48(3):195-8.

RESUMO - Contexto - Idade e, possivelmente, o gênero afetam a dinâmica da deglutição. Entretanto, a interação entre os efeitos da idade e do gênero na deglutição não é completamente conhecida. Objetivo - Avaliar a possível interação da idade e do gênero na dinâmica da deglutição. Método - A dinâmica da deglutição foi avaliada pelo teste de ingestão de água em 89 voluntários saudáveis, 43 homens e 46 mulheres, com idades de 20 a 40 anos (jovens, $\mathrm{n}=38$ ), 41-60 anos (meia idade, $\mathrm{n}=31$ ) e 61 a 80 anos (idosos, $\mathrm{n}=20$ ). Cada sujeito ingeriu em triplicata $50 \mathrm{~mL}$ de água enquanto eram medidos o tempo de ingestão e o número de deglutições necessárias para ingerir todo volume. Resultados - O intervalo entre deglutições e o volume em cada deglutição foram menores nas mulheres, quando comparadas aos homens. O tempo para ingerir os $50 \mathrm{~mL}$ de água foi maior, o intervalo entre deglutições foi maior, o fluxo de ingestão e o volume em cada deglutição foram menores em pessoas idosas quando comparadas com pessoas jovens e de meia idade. O fluxo de ingestão foi menor nas mulheres, comparado ao fluxo dos homens, somente entre os sujeitos jovens. O volume em cada deglutição foi menor nas mulheres do que nos homens entre os sujeitos jovens e de meia idade. Não houve diferença no fluxo de ingestão e no volume em cada deglutição entre homens e mulheres idosos. Conclusão - Idade e gênero têm influência na deglutição, com o efeito do gênero mais evidente nos sujeitos jovens, e o efeito da idade mais evidente nos homens.

DESCRITORES - Efeito idade. Identidade de gênero. Deglutição. 


\section{REFERENCES}

1. Achem SR, DeVault KR. Dysphagia in aging. J Clin Gastroenterol. 2005;39:35771.

2. Alves LM, Cassiani RA, Santos CM, Dantas RO. Gender effect on the clinical measurement of swallowing. Arq Gastroenterol. 2007;44:227-9.

3. Alves LMT, Cassiani RA, Santos CM, Dantas RO. Avaliação da deglutição pelo teste de ingestão de água. GED Gastroenterol Endosc Dig. 2007;26:1-4.

4. Alves LMT, Santos CM, Cassiani RA, Dantas RO. Dinâmica da deglutição de líquido em pessoas obesas. GED Gastroenterol Endosc Dig. 2007;26:18790 .

5. Chee C, Arshad S, Singh S, Mistry S, Hamdy S. The influence of chemica gustatory stimuli and oral anaesthesia on healthy human pharyngeal swallowing. Chem Senses. 2005;30:393-400.

6. Cook IJ, Weltman MD, Wallace K, Shaw DW, Mckay E, Smart RC, Butler SP. Influence of aging on oral-pharyngeal bolus transit and clearance during swallowing: scintigraphic study. Am J Physiol. 1994;265:G972-7.

7. Dantas RO, Ferriolli E, Souza MA. Gender effects on esophageal motility. Braz J Med Biol Res. 1998;31:539-44.

8. Dantas RO, Alves LMT, Cassiani RA. Gender differences in proximal esophageal contractions. Arq Gastroenterol. 2009;46:284-7.

9. Dantas RO, Alves LMT, Cassiani RA, Santos CM. Clinical measurement of swallowing and proximal esophageal contractions in Chagas' disease. Esophagus. 2009;6:231-6.

10. Dantas RO, de Aguiar Cassiani RA, dos Santos CM, Gonzaga GC, Alves LMT, Mazin SC. Effect of gender on swallow event duration assessed by videofluoroscopy. Dysphagia. 2009;24:280-4.

11. Dantas RO, Alves LM, Dalmazo J, Santos CM, Cassiani Rde A, Nascimento WV. Effect of age on proximal esophageal response to swallowing. Arq Gastroenterol. 2010;47:339-43.

12. Dantas RO, Alves LM, Cassiani Rde A, Santos CM. Evaluation of liquid ingestion after bariatric surgery. Arq Gastroenterol. 2011;48:15-8.

13. Ferriolli E, Dantas RO, Oliveira RB, Braga FJ. The influence of aging on oesophageal motility after ingestion of liquids with different viscosities. Eur J Gastroenterol Hepatol. 1996;8:793-8.

14. Gluckman A. Sexual dimorphism in human and mammalian biology and pathology. New York: Academic Press; 1981.
15. Hamdy S, Jilani S, Price V, Parker C, Hall N, Power M. Modulation of human swallowing behavior by thermal and chemical stimulation in health and after brain injury. Neurogastroenterol Motil. 2003;15:69-77.

16. Hughes TA, Wiles CM. Clinical measurement of swallowing in healthy and in neurogenic dysphagia. QJM. 1996;89:109-16.

17. Kang BS, Oh BM, Kim IS, Chung SG, Kim SJ, Han TR. Influence of aging on movement of the hyoid bone and epiglottis during normal swallowing: a motion analysis. Gerontology. 2010;56:474-82.

18. Kurosu A, Logemann JA. Gender effects on airway closure in normal subjects. Dysphagia. 2010;25:284-90.

19. Lang IM. Brain stem control of the phases of swallowing. Dysphagia. 2009;24:333-48

20. Lawless HT, Bender S, Oman C, Pelletier C. Gender, age, vessel size, cup vs. straw sipping, and sequence effects on sip volume. Dysphagia. 2003;18:196-202.

21. Logemann JA, Pauloski BR, Rademaker AW, Kahrilas PJ. Oropharyngeal swallow in younger and older women: videofluoroscopic analysis. J Speech Lang Hear Res. 2002;45:434-45.

22. Nascimento WV, Cassiani RA, Dantas RO. Gender effect on oral volume capacity [abstract]. Dysphagia. 2010;25:394.

23. Nathadwarawala KM, McGroary A, Wiles CM. Swallowing in neurological outpatients: use of a timed test. Dysphagia. 1994;9:120-9.

24. Perlman AL, Schultz PG, VanDaele DJ. Effect of age, gender, bolus volume, and bolus viscosity on oropharyngeal pressure during swallowing. J Appl Physiol 1993;75:33-7.

25. Robbins J, Hamilton JW, Lof GL, Kempster GB. Oropharyngeal swallowing in normal adults of different ages. Gastroenterology. 1992;103:823-9.

26. Shaker R, Ren J, Podvrsan B, Dodds WJ, Hogan WJ, Kern M, Hoffmann R, Hintz J. Effect of aging and bolus variables on pharyngeal and upper esophageal sphincter motor function. Am J Physiol. 1993;264:G427-32.

27. van Herwaarden MA, Katz PO, Gideon RM, Barrett J, Castell JA, Achem S, Castell DO. Are manometric parameters of the upper esophageal sphincter and pharynx affected by age and gender? Dysphagia. 2003;18:211-7.

28. Vega KJ, Palacios C, Langford-Legg T, Watts J, Jamal MM. Gender variation in oesophageal motor function: analysis of 129 healthy individuals. Dig Liver Dis. $2010 ; 42: 482-4$

Received 23/3/2011 Accepted 10/5/2011 